\title{
Political Leadership in South Korea's Developmental State: A Historical Revisit
}

\author{
Ratu Ayu Asih Kusuma Putri
}

Bina Nusantara University, Indonesia

\begin{abstract}
South Korea under President Park Chung Hee underwent rapid industrialization and experienced phenomenal economic growth making the country one of the Asian Tigers alongside Hong Kong, Taiwan, and Singapore. Had suffered by the long-standing Japanese colonialization, South Korea's development strategies in its incipient economic venture, interestingly, postulate unforeseen similarities with those imposed by Japan primarily during the phenomenal industrial revolution of the Meiji government (18681912). Exponential modernization in South Korea was substantially forged by the implementation of 'developmental state' model. The term was initially coined by Johnson (1982) to explain the pacification of government policies - rather than market - to achieve successful economic rejuvenation of post-war Japan. In light to this historical paradox between South Korea and Japan, this article attempts to revisit the embarking point of South Korea's rapid economic development beginning in the 1960s by drawing attention to the importance of leadership as one of the major components of the developmental state model. It concludes that Park Chung Hee's strong Japanese linkage combined with his pretext for imposing 'hard authoritarianism' is particularly influential in determining South Korea's pragmatic development trajectory.
\end{abstract}

Key words: developmental state, South Korea, Park Chung Hee, modernization, leadership

\section{Introduction}

The behind-the-scenes animosity of South Koreans to Japan is inevitable. Despite the shared cultural heritage and close geographic positions, some unpleasant contacts since the ancient period culminated during the annexation of Korea in 1910 emotionally afflicted the two countries' view of each other and led to a prevailing sense of rivalry even until today. The harsh colonial rule, 'Japanization' policy, and ruthless exploitation of Koreans by the Japanese had consequently built a deep hatred amongst Koreans toward Japan. Conversely, as Lee (1985) points out that most Japanese are disdainful and intolerant of Korea, do not understand and are insensitive to the feelings of Koreans, and do not wish to be involved with anything related to Korea, unless, there are rational reasons for doing so. Although there has been a significant shift toward the much better relationship between the two, these emotions are not 
easily extinguished especially amongst the old generation and the more conservative population. Japanese and Korean can form lasting friendships and working relationships at the individual level, yet there is no sense of genuine friendship at the collective or societal level.

Despite the bitter relationship, South Korea's successful development policies in the 1960s demonstrate striking similarities with those imposed by Japan during the Meiji's industrial revolution and Japan's post-war economic renaissance. Once pronounced as one of the poorest countries in the world after suffering from the devastating Korean War, South Korea emerged as a global economic power in a relatively short period. Albeit being on the American side, South Korea demarcated from the marketbased liberal economy and instead imposed an 'interventionist state pattern' to boost its economy, a pattern first instituted by the Meiji government during the industrial revolution in Japan (Kim \& Jaffe, 2010). The pattern demonstrates a state-centric development or state-driven economic growth in which state utilizes its effective control of the national economy to pursue their global economic interests (Johnson, 1982; Amsden, 1989; Tønnesson, 2017). The pattern distinguishes the East Asian model of development in comparison to the Western model that supports minimization of state intervention.

In the early stage of its rapid economic expansion, South Korea emulated the 'developmental state' model, pioneered by Japan, to a significant degree. In addition to placing the centralized state as the engine powering the industrialization, most notable similarities can be seen on the prominence of military power to ensure internal and external stability; its focus on heavy and chemical industries; and the interlocking relations between the state and the business groups (chaebol, similar to Japan's zaibatsu) that were given incentives by the government to develop industry deemed vital to development and state's interests. South Korea's economic take-off began during Park Chung-hee's rule (1961 1979) after a military coup he initiated against Chang Myon's administration. Immediately after assuming power, Park imposed some policies oriented to the goal of rapid industrialization such as the nationalization of country's financial assets, including the banking system; and the acceleration of foreign loans inflow to the chaebol with both the principle and interest were guaranteed by the government (Minns, 2001).

Park's administration had significantly been inspired by the Meiji government's principle of "rich state and strong army policy" (fukoku kyohei). In the early 1970s, Park shifted its industrial emphasis from light manufacturing towards heavy and chemical industries. The shift was exponentially driven by the US retrenchment post-Vietnam War and its détente with the Soviet Union that consequently decreased its reliability. Park imposed the Heavy and Chemical Industry Plan (HCIP) to provide the capability for self-defense and focus on 
the production of steel, petrochemicals, electronics, and shipbuilding (Minns, 2001). To ensure internal stability, the regime ensured order and stability through a nationally organized and centrally responsive police and intelligence structures as instruments of rule (Cumings, 1984). Opposition parties were effectively banned during the Fourth, and Fifth Republics and their leaders were subjected to harsh treatment, including imprisonment. Any opposition should be suppressed to keep the whole aspects of state under its control. Moreover, control over the media has been stern (Eckert, 1991). On the other words, Park defaulted on the Western bloc's most cherished ideas of free elections, liberal democracy, fundamental human and political rights. The South Korean modernization is characterized by particularly acute tensions and discrepancies between effective strategies of development and ideological hypocrisy (Kim K., 2006). The U.S. approach of supporting the Global South's undemocratic and authoritarian regimes during the Cold War, nevertheless, was common and unsurprising. The need to contain the spread of communism became the strategic imperative to tolerate the atrocious rule of such regimes and to justify their postwar economic reconstruction effort (Wong, 2004). In turn, these regimes accommodate the United States to gain benefits from aid, investments, and market access and eschew from becoming targets of its hostility (Tønnesson, 2017).
Against this backdrop, this article aims to elucidate the historical paradox between South Korea and Japan through a micro-analysis of political leadership focusing on the role of Park Chung Hee as the developmental state elite. In the next section, I will elaborate on the developmental state model and how the role of political leadership is prominent when applying the model. The sections thereafter will explain the features of the Japanese developmental state model particularly during the Meiji restoration and the 'presumed' Japanese legacies prevalent to South Korea's subsequent development. Lastly, this article will explore the role of Park Chung Hee in actualizing the Japanese developmental state formula to South Korea by reflecting on his personal and professional ties with Japan.

\section{Developmental State Model: The central role of political leadership}

Many observers illustrate the successful modernization process in some countries in East Asia using the developmental state paradigm. The term developmental state is coined by Chalmers Johnson (1982) in his seminal work on Japan's post-war development. The Japanese formula has been described as 'plan rational state' or 'plan-oriented market economy' to substantially elucidate the intimate relationship of state with the private sector and the intensity of its involvement in the market (Johnson, 1982). Beeson (2009) posits that unlike "market rational" state that concerns with simply establishing the rules of the 
economic game, the "plan rational" states sought to formulate and pursue substantive social and economic goals. A developmental state model is defined by some significant components which include a determined developmental elite who effectively conceives executive dominance, creates bureaucratic unity, and a powerful, competent and insulated economic bureaucracy; selective and strategic use of resources and instruments; the effective management of non-state economic interests; and the use of repression, legitimacy and performance which in corollary sustain a weak and subordinated civil society (Johnson, 1982; Amsden, 1989; Haggard, Kim, \& Moon, 1991; Leftwich 1995; Tønnesson 2017). A developmental state is also characterized by the path dependency, institutional cohesion and the interlocking patterns of political and economic power that are such a ubiquitous and distinctive part of development in East Asia (Beeson, 2009).

The core component of the developmental state is political leadership that accentuates executive dominance and embodies determined developmental elite. A developmental state has to be governed by determined and economically oriented elite. Political leadership is central in choosing and realigning economic policies by political rationality and 'developmental ideology' (Johnson 1989; Amsden, 1989; Moon \& Prasad, 1994). Leader's motivations and calculations are the vital clues to priority shift and policy change that usually require a perceived crisis among the population and for the new priorities to resonate with the emotional needs of public opinion (Moon \& Prasad, 1994; Tønnesson, 2017). Sakata \& Hall (1965) on their study about Meiji Restoration argue that study of the motives of the political leaders is a formidable task to explain the figures who were to lead the way in the creation of a new structure of state and society. Leadership style, therefore, determines how the executive dominance in a developmental state is being enforced (reigning vs. ruling). Amsden (1989) suggests the importance of 'learning' rather than invention or innovation as the basis of industrialization which is relevant to the context of South Korea. Manufactures were initially developed and competed from borrowed technology which later optimized. They created products similar to those internationally available but with improvements in the specification and lower price thus enhance competitiveness (Amsden, 1989).

Other incremental features of determined developmental elites include the intimate linkage of their civil and military bureaucracy and high political components; and the strong patron-client relations that eventually prompted the practice of corruption, technocratic economic management, patrimonialism, and coercion. Leftwich (1995) further asserts the importance of the executive head of government who plays an instrumental role in establishing the developmental regime and its culture. Moon \& Prasad (1994) examines the bureaucratic-executive nexus in the countries where executive dominance prevails. They posit that in such case, 
policymaking is profoundly top-down, and bureaucrats hardly have autonomy and power. For instance, South Korea during Park Chung Hee regime, the nexus was rigidly vertical in which the President controls the concentration of administrative and personnel power. Korean bureaucrats were structurally dependent on and vulnerable to the President (Moon \& Prasad, 1994). In the East Asian context particularly during the Cold War, the emergence of 'hard authoritarian' regimes were the common historical precondition for developmental state model to take place. Hard authoritarian regimes penetrate and prevail over civil society, and organized, subsidized, and controlled social groups (Moon \& Prasad, 1994). Most of such regimes in East Asia commonly obtained their political source of the relative state autonomy through military coup d'état or forced transmission of state power (Leftwich, 1995). Traditionally, developmental regimes use the historical mission to deter communist forces to justify their concentration of power and nondemocratic practices hence legitimate the state's intervention in a wide array of civil society's activities.

\section{The Unbroken Lineage between South Korean and Japanese Developmental State?}

This section will examine the features of the Japanese developmental state model notably that implemented during the Meiji Era, and the Japanese colonial legacies which presumably had laid a necessary foundation for South
Korea's development. The locus of this study is Meiji restoration, and the subsequent modernization of Japan as the foundational establishment of the Japanese developmental state model occurred during the period. Even the Japanese post-World War II economic development indicated a replication of the reform formula of Japan's Meiji era (Tønnesson, 2017).

\section{Distinctive Features of Japanese \\ Developmental State Model in the Meiji Era}

(1868-1912)

What makes the Japanese development model - particularly that of the Meiji era - different from the Western model? The Japanese model of development is recognized as the developmental state system where the state has dominant control over economic development. The government involvement in economic affairs is following 'the command and control' mode. The command and control mode demonstrate the extent of the military organizations' reliance on the hierarchy and direct commands as well as central planning in which bureaucrats set production targets and quotas for farms and manufacturing firms (Mosk, 2008). At an early stage of its industrial development Japan was so poorly endowed by raw materials to support industrialization. The strategy to overcome this was to become an exporter of industrial goods to ensure foreign exchange availability which can be used to import raw material and to meet the cost of imported technology and expertise 
required to 'catch up' with other industrial countries (Breen, 1997).

The Japanese model of development can be understood by observing the historical, political and social aspects that establish the distinctive features of this model. The Japanese unprecedented rapid development was led by the Meiji Restoration (Meiji Ishin) starting in 1868 through the restoration of the imperial rule in Japan. Some historians argue that the breakdown of feudal economy and weakening defense capability during the late period Tokugawa had led to the increased threat of foreign invasion by the Western powers and caused widespread resentment against the shogunate (Sakata \& Hall, 1956). The restoration was trademarked as a 'revolution from above' to modernize and maintain independence from a threatening West. After the coup which ended the Tokugawa rule, the Meiji oligarch leaders, consisting of those from Satsuma and Chōsū, launched a rapid program of industrialization emphasizing economic development as the key of security and to escape the country from backwardness (Ginsburg, 2001). The Restoration led to enormous changes in Japan's political and social structure which marked as the starting point of Japanese modernization. It created an immensely powerful central government; abolished warrior privileges and open the administration office to anyone with the required education and skills; and instituted a compulsory military service system and universal public education to all people (Mosk, 2008).
Meiji restoration has some distinctive features in its way of modernizing Japan. First, the most crucial element of the Meiji period was the principle of fukoku kyohei (enrich the country, strengthen the military) which explicitly aimed at absorbing Western technology and institutions in political, economic and military affairs with the ultimate aim of resisting the pressure of and subsequently repelling the Western power (Mosk, 2008). Macpherson (1987) posits that this xenophobic nationalism apparently dictated Meiji's rapid industrialization. As the industrialization became an economic underpinning of military power, the state particularly encouraged the import - then followed by the production - of indigenous technology and industry in fields such as steel, machine tools and shipbuilding (Alexander, 2008). Japan began to adopt the Western military technology, build arsenals and shipyards, establish technical schools, and invite foreign military advisers (Hacker, 1977). While internally, the politics of the early Meiji period were dominated by the need to extinguish domestic opposition particularly by the disgruntled samurai. Until domestic unrest could be squished, it would be difficult for the government's authority to effectively institute policy and force the public to comply with it.

Secondly, one of the corollaries of fukoku kyohei was the shokusan kogyo (encourage the manufacture and promote industry) led to the emergence of zaibatsu in Japan. It demonstrates a close interaction between government and 
manufacturing as well as between economic policy and industrial development. The government at all levels should assist industry by coordinating it, by taking a long view of development rather than the short-run emphasis on making annual profits characteristic of decentralized "invisible hand" capitalism, that can appreciate the input-output connections between different sub-sectors of manufacturing (Mosk, 2008). They see that the manifestation of shokusan kogyo could be achieved through the emergence of zaibatsu and the financial groups who controlled diversified economic empires, ranging from banking to insurance to international trade to textiles to iron and steel to shipbuilding to iron and steel manufacture. Through these strategies formulated by the Meiji oligarchs, Japan jumped rapidly into the phase of capital monopoly. On the other hand, Mosk (2008) argues that this strategy had a detrimental consequence to the emergence of a military-bureaucratic class who monopolizes capital in the form of the zaibatsu operating hand in glove with the authorities. The nation was hijacked by a tiny elite consisting of influential militarists and capitalists taking advantages from the government absolute power over the economy. The Japanese system is unique due to this compact system of networks between state agencies, and business firms coined as 'crony capitalism' which portray collusion between all parties rather than competition. Furthermore, in Japan's case, the state possesses the strength to penetrate and mobilize the society using the development narrative (Evans, 1995).
This relative autonomy, as Evans (1995) described, includes bureaucratic agencies that were not only capable and coherent but also manipulation of the society and close ties with the economic actors who in turn support the policy implementation and the 'guided' development.

\section{Presumption of 'Japanese Colonial Legacies'}

There is still an ongoing debate amongst Koreans - and scholars - about the Japanese colonial legacies on Korean development. Some argue that the Japanese colonization transformed Korea into a developmental state through the production-oriented policy and establishing a business-government alliance that facilitated industrialization (Kohli 1994; Kohli 1997; Kohli 2004; Cumings 1984). The colonial economy experienced steady growth and industrialization, but it also became rather heavily export-oriented, including exports of manufactured products. Besides, the colonial imposed brutal repression and systemic control of the lower classes in both the cities and the countryside. The cumulative impact of these state-class configurations was to create a framework for the evolution of a high-growth political economy (Kohli, 1994). Eckert (1991) further asserts that there is a continuity between colonial and postcolonial Korean economic structure, noting the common elements in both the development models: 'the pivotal economic function of the state, the concentration of private economic power in the hands of a few large business groups or chaebol (zaibatsu in Japanese 
terminology), the emphasis on exports, and the threat or actuality of war as a stimulus for economic growth.

Conversely, some skeptics argue that amidst a claim of economic growth in the colonial Korea, the record was relatively modest. Furthermore, there were restrictions on indigenous business activity, limited employment opportunity in both public and private sectors for Koreans, agricultural surplus and investments were primarily directed to military rather than economic imperatives (Haggard, Kang, \& Moon, 1997). There was a period gap between the end of Japanese rule and the beginning of Korea's economic takeoff in which Korea suffered from fundamental policy change and war. Much of the Japanese-financed capital was destroyed during the war. Lastly, the Japanese involvement in the emergence of Korean firms and entrepreneurs in the interwar period is questionable. Some of the current chaebols, like Samsung and LG (formerly LuckyGoldstar), had ostensibly begun their operations during the Japanese rule (Breen, 1997). It is argued that irrespective of Japanese colonialization, such firms would have emerged, although the Korean acquisition of Japanese assets had contributed to the rise of some economic groups in the 1950s (Haggard, Kang, \& Moon, 1997).

Why does the Japanese legacy become so essential in discussing the Korean model of development? As a starter, it is necessary to understand the nature of Japanese colonization in Korea.
Japan's annexation policy toward Korea was driven by its desire to become the hegemonic power in the region by building a mighty military might with the supports from the annexed states (Kim K., 2006). Thus, any 'modernization' policies and infrastructure built by the Japanese in the colonial Korea were selfishly motivated and most Koreans did not obtain any benefits from them (Kohli, 1997). It can be argued that leaving vital resources to support the future development in Korea is not of the prudent intention of Japan when colonizing the peninsula but merely an 'unintended' result of Japan's expansionist policy.

Before the Japanese annexation, Korea had been experiencing domestic instability due to some political riots as well as unequal agreements with foreign powers mainly Japan, China, the U.S., Germany, Russia, Italy, and France which resulted in weakening sovereignty of the country. These agreements significantly reduced Korea's control over ports, railways, and many other vital assets. Besides, corruption had become the common practice of the government officials and rigid social structure widened the economic gap between the higher social class and the lower class that consequently fueled resentment by the commoners against the government. After the assassination of Queen Min in 1895 by the Japanese and their Korean followers, political unrests were culminated and fueled by the increasing Japanese domination following the murder. Russia took advantage of this situation by forcing 
King Kojong to submit to the Russian legation in the hope that the foreign power can help deter the Japanese. However, after Japan's victory over Russia, the Treaty of Portsmouth assured Japan effective supremacy in Korea. Furthermore, the Agreements of 17 November 1905 and 24 July 1907 arbitrarily gave the Japanese government the rights to interfere in Korea's domestic affairs signaling the beginning of Japanese occupation (Kleiner, 2001).

Kohli (1994) argues the 'modernization' experience was the most plausible - if not instrumental - legacy of the Japanese colonialism. Korean capitalism learned from the provided framework established during the colonialization. The colonial power emphasis on building not only military and police forms of control but also the development of the peninsula under strong state auspices is a particularly instrumental lesson for the future Korean developmental elite. Japan had brought the access to modern technology and management. Managerial practices were changed in agriculture, industry, transportation, and government. For instance, Japanese government's deliberate promotion of modern agricultural practices such as irrigation, improved seeds, and the use of fertilizer had pushed productivity growth in colonial Korea (rice production rate of $2 \%$ per annum) (Kohli, 1994). Japan also introduced and utilized the "mighty trio" formula of the developmental state which is a coalition of the state bureaucratic organization, central banks, and zaibatsu conglomerates to industrialize Korea and parts of Manchuria (Cumings, 1984). Japan also located various heavy industries - steel, chemicals, hydroelectric power - in Korea and built an extensive network of railways in Korea (Cumings, 1984). However, much of those infrastructures were destroyed during the Korean War.

Japanese imperialism differs from its Western counterpart in several fundamental respects. Japan always sought to exercise a more intensive form of control over its colonies than European powers and to integrate its colonies into its economic structures. To facilitate economic exploitation and political control, the Japanese constructed a highly repressive, efficient, modern state in Korea. It exercised a pervasive and highly intensive form of control over all aspects of social and economic life in Korea (Piric, 2008). Japan distorted the structure of Korean society by replacing Confucian and other indigenous teachings into a disciplined colonial bureaucracy education. Other influences of the Japanese colonialization to the Korean education include large-size classes, a heavy emphasis on academic - rather than vocational - studies, moral education, deep respect for the authority of the teacher and a government-managed system of examinations for entrance to the high school and university (Mason, 1980). It has been argued that the Japanese transformed a relatively corrupt and ineffective traditional state into a modern one that was capable of transforming the society. One could argue that the Japanese 
Empire had significant contribution in liberating Koreans from the backwardness and stagnation, in which Koreans were otherwise unable to generate political and economic change (Palais, 1995). However, Eckert (1996) asserts that the authoritarianism that for decades epitomized South Korean politics after the Korean War owed much to the political character of the various Korean elites generated during the late-colonial period.

\section{Political Leadership of Park Chung Hee (1961-1979) and South Korean Developmental State}

Following the end of World War II, the relationship between the two countries develops in an intricate pattern. Japan and Korea (North and South) were engulfed in the post-war political realm as the world entered the tumultuous Cold War period. Korea was divided into the communist North and the 'nominally' liberal democratic South. Meanwhile, Japan began its pacifism era in which it drastically diminished any armed forces with war potentials. In the wake of Korean War (1950-1953), Japan and South Korea were awkwardly unified under the security patronization of the United States and inherently be an integral part of the global political contestation between the superpowers. South Korea and Japan had connected another link in their future where both countries are to prepare to enter the battlefield side to side, regardless their past chronicle, if the truce with North Korea is broken.
In the immediate aftermath of Korean War, South Korea evidenced the fall of Syngman Rhee, an anti-communist independence figure who was elected as South's first president, due to the widespread discontent of his iron-hand and corrupt government. A nation-wide protest eventually took place but was responded by police shooting which led to a subsequent chaotic mass riot. Rhee was ultimately ousted and replaced by Yun Bo-Seon as the President and Chang Myeon as Prime Minister. Despite the exit of Rhee, the political and economic instability persisted which provided a political opportunity for the military coup d'état, carried out by Park Chung Hee in 1961. Park was a high-rank military officer who had long initiated the establishment of the Military Revolutionary Committee within the military corps to plan the coup. The coup brought Park into power, and the subsequent approval and official recognition from the United States gave him the legitimate leadership status after that. Under Park administration, South Korea experienced a 'miraculous' modernization that turned the country from one of the poorest one in the world into one of the global economic powerhouses.

Essentially, Park Chung Hee has a significant Japanese influence in his life. Park Chung Hee had the primary education at Kumi Elementary School and Taegu Normal School, both of them using the Japanese educational system. There is a notion of Park Chung Hee being a cold and self-centered realist. It was reflected in his elementary school days where he 
always carefully calculated his strategy and enjoyed exercising the authority given to him. He also had a great attraction to soldiering since a very young age. After spent some years becoming a teacher in Munkyong, he got a chance to be an army by receiving Japanese military education in Japanese-occupied Manchuria and Imperial Japanese Army Academy for several years. This Japanese experience was seen as a vital component in the character of Park's future rule. Not only was he exposed to Japanese military planning, but he and his fellow Korean officers were imbued with the Japanese attitude of placing the interests of the group and nation before personal or family interest. In this sense, they were much less typically Korean than the preceding generations. Even after he became the President of South Korea, he still showed the mentality and behavior of a Japanese (Breen, 1997).

It was observed that Park Chung Hee, mentally, was obliged to think "Japanese," by devoting to the Yamato spirit of "one hundred million hearts beating as one," and giving the loyalty and self-sacrifice to the emperor (Kim H.A., 2004). Park Chung Hee was even accused of being a pro-Japanese due to his action of submitting the Oath of Allegiance demonstrating his devotion to the Japanese Empire (Hankyoreh, 2009). Park was also seen as having the ambition to reinvent his identity as a 'victorious' Japanese Army officer. Within just three months of being in the army, Park voluntarily Japanized his name to Takaki Masao. It was described that Park Chung
Hee looked like a Japanese soldier from the way he sat and stood to his actions characterized by his accuracy, speed, decisiveness and his action-oriented based character. Park graduated from the military academy with an excellent record and the Emperor of Manchuria Henry P'uYi awarded Park a gold watch for his academic excellence (Kim H.-A., 2004).

There are some policies and development strategies imposed by Park Chung Hee demonstrating the significant influence of his Japanese experience. Had it not been Park Chung Hee, it could be unlikely for South Korea to adopt the Japanese developmental state model to an unprecedented degree. The most fundamental policy was the normalization of South Korea-Japan relations in 1965 in exchange for Japanese aid and investment. By February 1964, just a little over a month after Park's presidential inauguration on 27 December 1963, normalization talks between Japan and Korea began. Normalization of Korea's relations with Japan had also been part of the US policy from 1947 as part of the US containment strategy, which was designed to make Japan a partner in the Cold War against communism. The US policy regarding normalizing Korea-Japan relations demonstrates a shift from demilitarization and democratization toward economic rehabilitation to create a dominant anti-communist force in NorthEast Asia. In contrast to Syngman Rhee's anti-Japanese stance, Park Chung Hee made a bold move to support this normalization idea. He visited Japan's Prime Minister Ikeda in Tokyo in 
November 1961 and talked not only with Ikeda but also many Japanese business leaders. Although Park's primary interest was economic, this move shows his flexibility in dealing with Japanese compared to the former regimes.

Park Chung Hee was seen to be greatly inspired by the Meiji Restoration's principle that emphasizes the need of economic development to strengthen the military in order to resist the potential threat (fukoku kyohei). Park's "Administrative Democracy" or "Koreanized Democracy" was the public rationale for his military-style administration, which, he claimed, was necessary to root out the past and to construct a new generation of national leadership comprising former military officers, technical engineers and other experts with professional qualifications (Kim H.-A., 2004). Park Chung Hee mentioned that:

"I want to emphasize, and reemphasize, that the key factor of the May 16 Military Revolution was to effect an industrial revolution in Korea...I must again emphasize that without economic reconstruction, there would be no such things as triumph over Communism or attaining independence." (Park Chung Hee) (Kim H.-A. , 2004)

This statement demonstrates how the potential threat from the North drives the economic development view of the South Korean leader. His regime rejected the use of force against North Korea and instead stressed the need to build national strength and security through economic modernization. In this manner, Park wished to win over the communist in the North.

The 'mighty trio' formula of Japan's Meiji was replicated during Park Chung Hee regime with the presence of the Economic Planning Board (EPB), state's control over the nationalized banking system, and the role of the chaebol. Only months after he assumed power, Park nationalized the banking system and controlled $96,4 \%$ of the country financial assets by 1970 (LueddeNeurath, 1988). Economic planning was taken seriously in South Korea during Park Chung Hee administration where he set up the Economic Planning Board (EPB), the Ministry of Finance, and the Ministry of Commerce and Industry as the core economic bureaucracies. These ministries held the responsibility to combine the budgetary and planning powers and had tremendous power over economic decision-making (Haggard, Kim, \& Moon, 1991). Organized business groups are regularly consulted on matters affecting the private sector, but it is evident that such groups exercise no influence on the country's decisionmaking (Mason, 1980). Institutions are structured to facilitate this participation, and there is ample testimony that President Park and his economic secretariat in the Blue House were fully engaged in the process. Park subjugated bureaucrats under his grip and dictated virtually every policy detail (Moon \& Prasad, 1994). 
The South Korean pattern of development has a strong sense of nationalism on it which demonstrates another similar pattern with the fundamental factor driving the Meiji restoration. While the threat of Western invasion ostensibly drove the Meiji regime's modernization policy, South Korea's economic development was defined to address the threat from the North. Unlike Western companies, whose raison d'etre is to increase the wealth of their shareholders, Korean firms were substantially established and existed for nation-building. Thus, Korea appeared to be a capitalist country on the surface, whereas on the inside its practices and attitudes made it look much more socialist (Breen, 1997). It was during the Park Chung Hee regime that business conglomeration structure (chaebol) gained its momentum. Park particularly wanted firms that could compete internationally with the Japanese. He thought that, as Koreans were not hard workers, and, as businesspeople and politicians were corrupt, a few loyal and capable lieutenants would be more effective than the vast army of small and medium business people. There was a risk that the development of large, powerful groups could provide power bases for ambitious tycoons to challenge his authority. However, Park Chung Hee thought he was able to control the chaebol with his hard authoritarian and militaristic approach (Breen, 1997).

Another similarity between Park Chung Hee's strategy and the Meiji regime was the use of Western economic and technological advance without necessarily adopting the Western model of development. The developed West, in general, was crucial to the Koreans for its technological import. Korean growth was possible because Korean workers were cheap and disciplined, and educated enough to learn how to use or copy foreign machines (Breen, 1997). Although independence is the main emphasis in Park Chung Hee's idea of economic development, he understood the importance of the alliance with the U.S. for Korea's growth. The U.S. government provided a security shield against possible renewed conflict with North Korea, and a market for Korean products. There have been tensions and difficulties, but the benefit to Korea was that it was both in American strategic interest and a natural consequence of American values as a nation born in opposition to imperialism, that its client state grows economically and politically from near-total dependency to equal partnership.

Ultimately, following the path of the Meiji government on extinguishing the corrupt Tokugawa rule, Park Chung Hee also had been enforcing the resurrection of Korean national character, primarily those in support of economic development since the national character on his view was - to some extent - had been polluted during the Choson Dynasty era, the last dynasty of Korea prior to the Japanese annexation. During his presidency, Park Chung Hee was known as a supporter of anti-elitist and anti-populist ideals, which were manifested in the self-restrained and disciplinary atmosphere (Han, 2004). Park 
was one of the most financially disciplined dictators in history showed his strictness in handling political funds in an attempt to prevent corruption, especially within the elite circle. Immediately after taking power, he launched an anti-corruption campaign.

\section{Reflection on Indonesia's Past and Present}

South Korea's developmental state model somewhat mirrors Indonesia's experience during the New Order regime led by Suharto (1967-1998). Both Park Chung Hee and General Suharto had a military background and rose into power through a military coup in around the same period. Suharto's regime, dubbed as the New Order, also combined a successful economy-first policy with hard authoritarianism and harsh internal repression. Upon assuming power, Suharto deliberately abandoned his predecessor's confrontational policy against Malaysia and instead formed the Association of Southeast Asian Nations (ASEAN) in 1967 with the former enemy. Furthermore, he sought rapprochement with Japan, Indonesia's former colonial. Indonesia experienced remarkable economic growth and development throughout the 1970s and 1980s. Industrialization was undertaken by conglomerates, mostly of ChineseIndonesian descendants, who dominated the nation's economy even until now. Suharto was consolidating both his power over the army and bureaucracy and the Indonesian developmental state by winning over support or buying off opposition (Leftwich, 1995). However, this strategy consequently provided a fertile ground for the high-level corruption which contributed to the regime's downfall in the late 1990s. Following the economic crisis in 1998, the regime was unable to sustain the domestic political unrest and the wave of democratization which subsequently ended the regime 31year rule.

Amidst demonstrating similar patterns, Indonesia failed to reach South Korea's level of modernization. It can be argued that Indonesia has lost the momentum to modernize the country due to the regime's inability to control corruption and sustain the emerging domestic political forces. The question is whether the developmental state is still relevance in the current political and economic context? Indonesia's bitter experience with the authoritarian regime makes it difficult to maintain the old developmental state model which imposes the authoritarian political system. In a democracy, civil society and business sectors are more willing to criticize the government policy or challenge it. Moreover, greater trade and financial integration with other countries can hinder the state from taking full control over the state's economic process and financial assets. However, Hayashi (2010) argues that the developmental state is not necessarily extinct. The developmental state in the era of globalization needs to accommodate the global market strategically while maintaining the proactive role of the state. To achieve this trajectory, according to the developmental 
state formula, the political leadership should be assumed by determined developmental elite with a visionary economic orientation.

\section{Conclusion}

Despite its hatred and negative sentiments toward Japan due to the colonization experience, South Korea seems to adopt the Japanese model of development. This condition is contradictive with what South Korea was expected to do if it considers this negativity. With its close ally with the United States, there was a high possibility that South Korea could adopt the Western model of development instead of the Japanese one. As we could see that the main difference between the Japanese and Western model can be seen in the level of the state's role in the development process. While the Western model supports the market rational with less interference from the state, Japanese model implements a developmental state model in which the state holds effective control over the development process. By referring to the political leadership element within the developmental state concept, I argue that the role of Park Chung Hee is instrumental in South Korea's adoption of the Japanese developmental state model. Had it not been Park Chung Hee, it would be unlikely to happen. Park Chung Hee was a central figure that could make this paradoxical condition plausible due to his Japanese linkage and his trajectory about South Korea's modernization in its conjunction with the threat from North Korea.

\section{About the Author}

Ratu Ayu Asih Kusuma Putri is a faculty member and researcher at the Department of International Relations, Bina Nusantara University, Jakarta. She earned her Bachelor's degree in International Relations from Universitas Indonesia and Master's degree in International Relations from the Graduate Institute of Peace Studies, Kyunghee University, South Korea. Her specialized research interest has been primarily on the issues of forced displacement, human rights and democracy. Some of her recent works include those related to urban refugee management in Makassar city, the work of Rohingya self-organized organizations in Malaysia, and the role of digital game-based learning in studying International Relations.

\section{References}

Alexander, A. (2008). The Arc of Japan's Economic Development. Oxon: Routledge.

Amsden, A. (1989). Asia's Next Giant: South Korea and Late Industrialization. Oxford: Oxford University Press.

Asia Society. (n.d.). Korean History and Political Geography. Retrieved December 28, 2010, from Asia Society Web site: http://asiasociety.org/countries-his tory/traditions/korean-history-andpolitical-geography 
Bedeski, R. (1994). The Transformation of South Korea: Reform and Reconstruction in the Sixth Republic under Roh Tae Woo 1987-1992. London: Routledge.

Beeson, M. (2009). Developmental States in East Asia: A Comparison of the Japanese and Chinese Experiences. Asian Perspective, 3(2), 9.

Breen, M. (1997). The Koreans: Who They Are, What They Want, Where Their Future Lies. London: Routledge.

Buzo, A. (2007). The Making of Modern Korean. London: Routledge.

Cumings, B. (1984). The Legacy of Japanese Colonialism in Korea. In B. Cumings, The Japanese Colonial Empire: 1895-1945 (p. 479). Princeton: Princeton University Press.

Douglass, M. (1994). The 'Developmental State' and the Newly Industrialised Economies of Asia. Environmental and Planning, 26, 534-566.

Eckert, C. J. (1991). Korea Old and New: A History. Cambridge: Harvard University Press.

Eckert, C. J. (1996). Total War, Industrialization and Social Change in Late Colonial Korea. In R. H. Myers, M. R. Peattie, \& eds. (Eds.), The Japanese Wartime Empire, 1931-1945. Princeton: Princeton University Press.

Evans, P. (1995). Embedded Autonomy: States and Industrial Transformation.
Princeton: Princeton University Press.

Ginsburg, T. (2001). Dismantling the 'Developmental State'? Administrative Procedure Reform in Japan and Korea. The American Journal of Comparative Law, 49(4), 585-625.

Hacker, B. (1977). The Weapons of the West: Military Technology and Modernization in 19th-Century China and Japan. Technology and Culture, 18(1), 43-55.

Haggard, S., Kang, D., \& Moon, C.-I. (1997). Japanese Colonialism and Korean Development: A Critique. World Development, 25(6), 867-881.

Haggard, S., Kim, B.-k., \& Moon, C.-i. (1991). The Transition to Exportled Growth in South Korea: 19541966. The Journal of Asian Studies, 50(4), 850-873.

Han, S.-J. (2001). Modernization and the Rise of Civil Society: The Role of the "Middling Grassroots" for Democratization in Korea. Human Studies, 24(1), 113-132.

Han, S.-m. (2004). Community Movement: Park Chung Hee and the Making of State Populism in Korea. Pacific Affairs, 77(1).

Hankyoreh. (2009, November 6). Evidence of Park Chung Hee's Military Allegiance to Japan Surfaces. Retrieved from Hankyoreh: 
http://english.hani.co.kr/arti/englis

h_edition/e_national/386277.html

Hayashi, S. (2010). The Developmental State in the Era of Globalization: Beyond the Northeast Asian Model of Political Economy. The Pacific Review, 23(1), 45-69.

Hirono, R. (1988). Japan: Model for East Asian Industrialization. In $\mathrm{H}$. Hughes, Achieving Industrialization in East Asia (p. 241). Cambridge: Cambridge University Press.

Johnson, C. (1982). MITI and the Japanese Miracle: The Growth of Industrial Policy, 1925-1975. California: Stanford University Press.

Kim, B.-k. (2011). Introduction: The Case for Political History. In B.-k. Kim, \& E. Vogel (Eds.), The Park Chung Hee Era: The Transformation of South Korea. Cambridge: Harvard University Press.

Kim, H.-A. (2004). Korea's Development under Park Chung Hee: Rapid Industrialization, 1961-1979. London: Routledge.

Kim, K. (2006). The Development of Modern South Korea: State Formation, Capitalist Development, and National Identity. Oxon: Routledge.

Kim, M., \& Jaffe, S. (2010). The New Korea: An Inside Look at South Korea's Economic Rise. New York: American Management Association.
Kim, M., \& Jaffe, S. (2010). The New Korea: An Inside Look at South Korea's Economic Rise. New York: AMACOM.

Kim, Y. (2007). Neoliberalism and the Decline of the Developmental State. Journal of Contemporary Asia, 29(4), 441-461.

Kleiner, J. (2001). A Century of Change. New Jersey: World Scientific Publishing Co. Ptc. Ltd.

Kohli, A. (1994). Where Do High Growth Political Economic Come From? The Japanese Lineage of Korea's 'Developmental' State. World Development, 22(9), 1269-1293.

Kohli, A. (1997). Japanese Colonialism and Korean Development: A Reply. World Development, 25(6), 883-888.

Kohli, A. (2004). State-Directed Development: Political Power and Industrialization in the Global Periphery . Cambridge: Cambridge University Press.

Lee, C. (1985). Japan and Korea: The Political Dimension. Stanford: Hoover Institution Press.

Lee, H. (2014). A Comparative Study of East Asian Capitalism. Berkeley: IEAS Publication.

Lee, Y. (1997). The State, Society and Big Business in South Korea. London: Routledge.

Leftwich, A. (1995). Bringing Politics Back In: Towards A Model of the 
Developmental State. The Journal of Development Studies, 31(3), 400-427.

Luedde-Neurath, R. (1988). State Intervention and Export-oriented Development in South Korea. In White, Gordon (ed.). Developmental States in East Asia. London: The Macmillan Press.

Macpherson, W. (1987). The Economic Development of Japan: 1868-1941. Cambridge: Cambridge University Press.

Mason, E. S. (1980). The Economic and Social Modernization of the Republic of Korea. Cambridge: Harvard University Press.

Minns, J. (2001). Of Miracles and Models: The Rise and Decline of the Developmental State in South Korea. Third World Quarterly, 22(6), 1025-1043.

Moon, C.-I., \& Prasad, R. (1994, October). Beyond the Developmental State: Networks, Politics, and Institutions. Governance: An International Journal of Policy and Administration, 7(4), 360-386.

Mosk, C. (2008). Japanese Economic Development: Markets, Norms, Structures. Oxon: Routledge.

Palais, J. (1995). A Search for Korean Uniqueness. Harvard Journal of Asiatic Studies, 55(2).

Pang, E.-S. (2000). The Financial Crisis of 1997-98 and the End of the Asian
Developmental State. Contemporary Southeast Asia, 22(3), 570-593.

Piric, I. (2008). The Korean Development State: From Dirigisme to NeoLiberalism. London: Routledge.

Sakata, Y., \& Hall, J. (1956). The Motivation of Political Leadership in the Meiji Restoration. The Journal of Asian Studies, 16(1), 31-50.

Setton, M. (1997). Cong Yagyong: Korea's Challenge to Orthodox NeoConfucianism. Albany: State University of New York Press.

Tønnesson, S. (2017). Peace by Development. In E. Bjarnegård, \& J. (. Kreutz, Debating the East Asian Peace: What it is. How it came about. Will it last? (pp. 55-77). Copenhagen: NIAS Press.

Wong, J. (2004). The Adaptive Developmental State in East Asia. Journal of East Asian Studies, 4, 345362. 